\title{
MAKING THE MOST OF THE EU'S EXTERNAL COMPETENCES IN THE SOCIAL AFFAIRS' AREA: THE EU AND THE INTERNATIONAL LABOUR ORGANISATION
}

\begin{abstract}
Julija Brsakoska Bazerkoska*
Summary: This article argues that from a Union law perspective, and for greater legal certainty of third parties, it is important for the EU to be able to exercise its powers towards relevant international organisations in those areas where the EU has gained competences. There are cases where the EU has gained appropriate status corresponding to its competences, but this is not the case with the ILO where the EU still encounters difficulties in practice due to its insufficient status. The main focus of the article is on how the EU exercises its competences in the framework of the International Labour Organisation. Since the two organisations have overlapping spheres of activity, conflicts of norms between the EU and the ILO can occur in a number of fields. The article gives an overview of the complex and complicated procedure of coordination and its development.
\end{abstract}

\section{Introduction}

EU membership in international organisations has grown since the breakthrough case with EC membership in the FAO in $1991 .{ }^{1}$ The formula adopted within the amendments of the FAO constitution regarding the membership of Regional Economic Integration Organisations has proven to be the most suitable definition for EU membership. However, aside from the fact that there are international organisations, such as NAFO, where the EU replaces the Member States and it is alone the member, there are international organisations where the Union has competences in the working area of the organisation, but cannot become a member. This is the case with the International Labour Organisation (ILO), where the structure of the organisation does not allow the EU to become its member, even through the EU is competent for numerous issues dealt with within the ILO institutional structure.

\footnotetext{
Assistant Professor, Ss. Cyril and Methodius University, Faculty of Law, Skopje, Macedonia.

1 On 26 November 1991, the EC became the 161st member as Member Organisation of the FAO. Since it was the first time that the EC had become a member of a UN specialised agency, this accession represented an institutional step forward. The Food and Agriculture Organisation, as a UN Specialised Agency, had previously permitted accession only to States. Therefore, in order to enable EU accession, the FAO modified its Constitution. In modifying the membership opportunities and allowing Regional Economic Integration Organisations (REIOs) to become members, the FAO welcomed the EC as its member alongside EC Member States.
} 
This article shows that from a Union law perspective, and for greater legal certainty of third parties, it is important for the EU to be able to exercise its powers towards relevant international organisations in those areas where the EU has gained competences. There are cases where the EU has gained appropriate status corresponding to its competences, but this is not the case with the ILO where the EU still encounters difficulties in practice as a result of its insufficient status. The specific tripartite ILO structure does not allow the EU to become a member. Therefore, the Union has only observer status within this organisation that shares common goals and commitments with the EU.

The article gives an overview of the ways used by the EU to exercise its competences in the framework of the ILO. It argues that, even though the ECJ has established the duty of cooperation when external competence is shared and has provided that Member States must cooperate with the European Union in negotiating and implementing international agreements, the Court has not offered detailed proposals concerning the nature of this procedure. ${ }^{2}$

The article gives a short overview of EU-ILO relations and points to the different categories of competences assigned to the Union with the Treaty of Lisbon. Further, it defines Union competences in the working area of the ILO, arguing that in cases where the Union's external competence is exclusive, Member States have more limited scope for action. Through different case studies of the conventions adopted within the ILO, the article shows that if the convention in question comes within the Union's partly or wholly exclusive sphere of competence, the Member States may not ratify it. There are also cases where the EU Member States may denounce a convention if it is not in line with Union legislation. Since the two organisations have overlapping spheres of activity, the conflicts of norms between the EU and the ILO can occur in a number of fields. Therefore, different situations arise concerning action by the Member States, depending on whether competence is shared among the Member States or is exclusively vested in the EU. Through the case of the ILO Maritime Labour Convention, the specific solution in cases of the ratification of ILO conventions is explained. The adoption of Council Decisions that authorise the Member States to ratify, in the interests of the European Union, ILO conventions where the Union has competence to act has become a new Union practice in putting into action its external competences in the working areas of this international organisation.

\footnotetext{
2 ECJ, Ruling 1/78 delivered pursuant to the third paragraph of Article 103 of the EAEC Treaty - Draft Convention of the International Atomic Energy Agency on the Physical Protection of Nuclear Materials, Facilities and Transports [1978] ECR 2151; ECJ, Opinion 2/91 (Convention No 170 of the International Labour Organization concerning safety in the use of chemicals at work) [1993] ECR I-1061; and ECJ, Opinion 1/94 (WTO Agreements) [1994] ECR I-5267.
} 
The article argues that although the EU has come up with a solution in cases of the ratification of conventions by its Member States, the implications of exclusiveness for other stages of ILO work, such as negotiations and voting, are less clear. The Council Decision of 1986 indicated that it is for the Commission, acting in close cooperation with Member States and social partners, to negotiate concerning ILO conventions where there is exclusive Community competence. The decision was deemed compatible with the ILO Constitution, but there has been criticism from the social partners, which has led to the decision not being applied in practice. The complex and complicated procedure of coordination and its development within the ILO is explained in the final part of the article.

\section{Short overview of EU-ILO relations}

Against a background of exploitation of workers in the industrialising nations, the importance of social justice in securing peace was enthusiastically recognised after the end of World War I when, as part of the Treaty of Versailles, the International Labour Organisation was created in 1919. The belief that social justice is an essential foundation of universal peace is the central pillar of the ILO. Moreover, understanding of the world's economic interdependence and the need for cooperation to obtain similar working conditions in countries competing for markets was increasing. In these circumstances, the ILO Constitution was drafted by the Labour Commission set up by the Peace Conference. ${ }^{3}$ It resulted in a tripartite organisation, the only one of its kind that brought together representatives of governments, employers and workers in its executive bodies. The unique tripartite structure of the ILO emphasises dialogue among the key economic actors as a means of promoting social progress. ${ }^{4}$ The ILO is the only UN specialised agency where non-governmental delegates take part on an equal footing with governmental representatives.

The status of the Regional Economic Integration Organisations (REIOs) is not regulated with the rules of the ILO Constitution. There are also no rules to regulate the status of the European Union as such. There are different categories of participants in the ILO system. However, membership in the ILO is open only to states. The conditions for becoming an ILO member are provided in Article 1(2) - 1(4) of the ILO Constitution. The term observer in the ILO refers mainly to non-Member States which

\footnotetext{
3 The Commission was composed of representatives from nine countries: Belgium, Cuba, Czechoslovakia, France, Italy, Japan, Poland, the United Kingdom and the United States.

4 For more on the issue of social security within the ILO, see A Nussberger, 'Evaluating the ILO's Approach to Standard-Setting and Monitoring in the Field of Social Security' in EH Riedel, Social Security as a Human Right: Drafting a General Comment on Article 9 ICESCRSome Challenges (Springer 2007) 103-117.
} 
participate in the Conference. ${ }^{5}$ Other categories of participants include non-Member States, public international organisations, non-governmental organisations (NGOs) with a permanent consultative status, ${ }^{6}$ and NGOs that participate only when invited.

The lack of a special provision on REIOs within the ILO Constitution indicates that the ILO does not make a distinction between different international organisations. Article 12(1) of the ILO Constitution states in general that the ILO will cooperate with other public international organisations active in related fields. Article 12(2) of the ILO Constitution provides that:

The ILO may make appropriate arrangements for the representatives of public International Organisations to participate without vote in its deliberations.

Therefore, the EU is not a member of the ILO, but has observer status that provides it with the right to participate in the ILO; it has the right to speak, but the right to vote is excluded. All 28 EU Member States are members of the ILO and their combined financial contributions, both regular and extra-budgetary, constitute a significant part of the ILO budget. Moreover, the Union contributes to numerous ILO activities, programmes and projects through extra-budgetary contributions.

The EU-ILO relationship is very important, since in the past decade the European Union has committed itself to promoting the social dimension of globalisation. According to Orbie and Tortell, the Union has been able to export onto the world scene several elements of the European social model, which ensures that social and economic aims go hand in hand. ${ }^{7}$ The EU, through increased cooperation with the ILO and by means of its external trade policies, has focused on the promotion of labour standards internationally. In several policy documents it has highlighted its commitment to promote the social dimension of globalisation. In line with the report of the ILO World Commission on the Social Dimension of Globalisation, the Union considers this global governance objective in the widest sense as involving decent work, sustainable development, democracy and accountability, and gender equality. ${ }^{8}$ This covers a range of policies ${ }^{9}$ and policy instruments ${ }^{10}$ pursued in the EU's neighbourhood,

\footnotetext{
Article 2(3e), Article 14 (11) and Article 56 (8) of the Standing Orders of the Conference.

6 For example, the International Confederation of Free Trade Unions.

J Orbie and L Tortell, 'The New GSP+ Beneficiaries: Ticking the Box or Truly Consistent with ILO Findings?' (2009) 14 European Foreign Affairs Review 663.

8 ibid 665.

9 For example, jobs and decent work, health, education and social security.

10 For example, development aid, trade relations, social and development policies and political dialogue.
} 
in other parts of the world and in various multilateral institutions. EU initiatives have mainly focused on the promotion of international labour standards as defined by the ILO.

\section{EU external competences in relation to the ILO working area}

External relations are of vital importance to the Union and to its future development. The representation and relations of the Union with international organisations and third states depend mainly on the division of powers between the Union and its Member States. In the past, lacking Treaty provisions, the Court formulated guidelines which were very important for the Community's external actions and for the Union's actions thereafter. However, the Treaty of Lisbon for the first time groups the competences into different categories. It makes a distinction between exclusive, shared and complementary or supporting competences. ${ }^{11}$ Certain competences are allocated to exclusive and to complementary categories. Others are declared to be shared. The list of complementary competences that cover actions to support, coordinate or supplement the actions of the Member States does not include any fields of activity related specifically to external relations. However, the importance of the external dimensions of health, culture, tourism and education should not be underestimated. ${ }^{12}$ Exclusive competences include the customs union and the Common Commercial Policy (CCP), as well as issues connected with the conservation of marine biological resources and competition policy, which have a real or potential external dimension. ${ }^{13}$ This case of constitutional exclusivity, where the Member States are precluded from acting, is different from pre-emption which applies in the case of shared

\footnotetext{
11 According to Article 3 TFEU, the Union has exclusive competence in the following areas: (a) customs union; (b) the establishing of the competition rules necessary for the functioning of the internal market; (c) monetary policy for the Member States whose currency is the euro; (d) the conservation of marine biological resources under the common fisheries policy; (e) common commercial policy. Article 4 TFEU provides that shared competence between the Union and the Member States applies in the following principal areas: (a) internal market; (b) social policy, for the aspects defined in the Treaty; (c) economic, social and territorial cohesion; (d) agriculture and fisheries, excluding the conservation of marine biological resources; (e) environment; (f) consumer protection; (g) transport; (h) trans-European networ$\mathrm{ks}$; (i) energy; (j) the area of freedom, security and justice; (k) common safety concerns in public health matters, for the aspects defined in the Treaty. In the areas of research, technological development and space, the Union has competence to carry out activities, in particular to define and implement programmes; however, the exercise of this competence does not result in Member States being prevented from exercising theirs. Finally, Article 6 TFEU provides that the Union has competence to carry out actions to support, coordinate or supplement the actions of the Member States in the following areas: (a) protection and improvement of human health; (b) industry; (c) culture; (d) tourism; (e) education, vocational training, youth and sport; (f) civil protection; (g) administrative cooperation.

12 Article 6 TFEU.

13 Article 3 TFEU.
} 
competences. Article 2(2) TFEU makes a useful distinction, which is not always brought out clearly in the case law:

The Member States shall exercise their competence to the extent that the Union has not exercised its competence. The Member States shall again exercise their competence to the extent that the Union has decided to cease exercising its competence.

As can be seen from this quotation, pre-emption depends on Union action. ${ }^{14}$ Even though the exercise of shared competence may pre-empt the action of the Member States, the right to exercise their competence may also be returned to the Member States. ${ }^{15}$ The Treaty, further, includes the following in the category of exclusive competence:

The Union shall also have exclusive competence for the conclusion of an international agreement when its conclusion is provided for in a legislative act of the Union or is necessary to enable the Union to exercise its internal competence, or insofar as its conclusion may affect common rules or alter their scope. ${ }^{16}$

Furthermore, the Court of Justice defined the implied external competences of the Union by developing the doctrine of parallelism - in foro interno in foro externo - leading to the conclusion that externally the Union cannot go beyond the competences conferred on it internally. The Treaty of Lisbon added a few new explicit external competences for the Union. However, the use of implied competences still remains important. According to Cremona, implied competences have been 'constitutionalised' by the addition of a non-specific treaty-making competence for the Union. ${ }^{17}$ Namely, Article 216(1) TFEU inserts a clear statement on the existence of treaty-making competence even in those cases where the Treaty does not provide the Union with explicit competence, stating:

The Union may conclude an agreement with one or more third countries or international organisations where the Treaties so provide or where the conclusion of an agreement is necessary in order to achieve, within the framework of the Union's policies, one of the objectives referred to in the Treaties, or is provided for in a legally binding act of the Union or is likely to affect common rules or alter their scope.

\footnotetext{
14 On the issue of pre-emptive exclusivity, see A Dashwood, 'The Relationship between the Member States and the European Union/European Community' (2004) 41 CML Rev 372373.

15 Marise Cremona, 'Defining Competence in EU External Relations: Lessons from the Treaty Reform Process' in A Dashwood and M Marsceau (eds), Law and Practice of EU External Relations: Salient Features of a Changing Landscape (CUP 2008) 60.

16 Article 3(2) TFEU.

17 Cremona (n 15) 55.
} 
This Treaty provision aims mainly to increase legal certainty and to achieve a clearer definition of Union competences.

There are numerous ILO fields of activity, such as labour law and occupational safety and health, which have their counterparts in the EU's 'social dimension'. The social dimension within Union law consists of several areas: free movement of labour, employment, equal opportunities, occupational safety and health, labour law, working hours, social security for migrant workers and social insurance. The free movement of workers is dealt with in Articles 45-48 TFEU. Articles 151-161 TFEU deal with matters concerning occupational safety and health, social security and equal pay for women and men doing equal or equivalent work. These articles of the Treaty do not explicitly grant any external competence to the Union, but the principle of implied external competence can be applied in large areas of labour law. When the Union has acted internally to accomplish the objectives of the Treaty in the field of labour law and social policy, it has also had external competences in the corresponding field.

In the areas where the EU has exclusive external competence, the Member States' freedom of manoeuvre within the ILO is restricted correspondingly by the EU's legislation. The Member States may not ratify an ILO convention coming within the EU's exclusive competence. However, in the fields that are covered by Union law, assuming they are not exclusive, the Member States can ratify a convention strengthening the Union rules. According to the ECJ, ${ }^{18}$ the Member States shall not be impeded from introducing more extensive rules.

\section{How can the EU put into action its external competences within the ILO?}

Although the EU is not a member of the ILO, the relationship between the two is especially important since EU competences greatly coincide with those of the ILO. Below we examine how the Member States and the EU have cooperated on particular issues put on the ILO agenda. We shall also study ECJ opinions on the role of the EC in the ILO.

\subsection{ILO Convention 153}

It was in 1977 that the issue of participation in negotiations leading to ILO conventions first arose within the European Community which was not a member of the ILO. This issue started to be considered when ILO Convention 153 on working hours and rest periods in road transport was negotiated. The issue that was discussed within the ILO was covered by EEC Regulation 543/69 of the Council of March 1969. The regulation

18 ECJ, Opinion 2/91 (n 2). 
referred to the harmonisation of certain social legislation relating to road transport. ${ }^{19}$ According to the European Commission, this issue was already part of EC competences. Therefore, the Commission sent a communication to the Council considering the conclusion of the Convention. ${ }^{20}$ The Commission's standpoint within the communication was that the Member States cannot any longer ratify international conventions relating to matters that come within the scope of the Community's powers. ${ }^{21}$

The Council communicated this issue to the ILO. The main points within the two working documents for the Governing Body of the ILO, aimed at facilitating Community participation, are outlined in ECJ Opinion 2/91:

In essence, those two documents provided, with regard to the negotiations, that Community Member States could authorize the Commission to propose amendments on their behalf, that the authority referred to in Article 19 of the ILO Constitution might be the Council and finally, with regard to ratification, that this could be done through an appropriate statement by the Community, provided that prior notification from all the Member States confirm that this measure constituted ratification by the Twelve.

Those documents also referred to the commitments undertaken by Member States which have ratified a convention. They point out in this connection that Member States alone can be held liable for failure to comply with those undertakings, even if the breach of the provisions of such a convention is attributable to a Community measure adopted by majority decision. ${ }^{22}$

Nevertheless, the employers and trade union organisations were reluctant to accept this solution. They refused to acknowledge that the Community might play a role in the ILO that would go beyond the mere status of observer at the Conference. Both sides of industry feared that it would reduce their own influence in the Conference. ${ }^{23}$ The effects of regionalisation and mainly the effects of the Community's coordination of the position of its Member States were seen as an attack on the unique

\footnotetext{
19 Council Regulation (EEC) No 543/69 of 25 March 1969 on the harmonisation of certain social legislation relating to road transport [1969] OJ L77/49.

20 Commission, 'Communication on the ratification by the Community of international conventions drawn up by the International Labour Organization including Convention No 153 concerning hours of work and rest periods in road transport' COM (80) 315 final, June 1980.

21 ibid.

22 ECJ, Opinion 2/91 (n 2) part IV - Community participation in negotiations leading to ILO conventions.

23 Rachel Frid, The Relations Between the EC and International Organisations: Legal Theory and Practice (Kluwer Law International 1995) 293.
} 
position that the social partners were enjoying under the ILO working procedures. ${ }^{24}$ Therefore, the solutions proposed and outlined in the working documents explained above were not endorsed. The attitude of the social partners on one hand and the unwillingness of some governments to see a more active role for the Community within the framework of the ILO on the other were the main reasons for this. ${ }^{25}$

Although the position of the European Commission on the issues connected with the negotiation process of ILO Convention 153 was not acknowledged, the Commission sent a common reply to the ILO questionnaire. This was done even though the role of the Community within the ILO was not recognised. The replies were given under the title 'States Members of the European Community' and included the replies of different organisations of social partners from different Member States. ${ }^{26}$

Finally, after Convention 153 was adopted by the ILO, it was communicated to all Member States in order to bring the Convention before the authority within whose competence the matter lies, for the enactment of legislation or other action. ${ }^{27}$ The only Member State of the EC that submitted Convention 153 to its Parliament was Germany. The submission was made in $1992 .{ }^{28}$ However, by October 2013, ILO Convention 153 was ratified by nine countries, and Spain is the only EU Member State among them. However, the ratification from Spain came in February 1985 , before the country became a member of the Union.

\subsection{ILO Convention 162}

In 1983, the dilemma of Community competence in the context of the ILO arose once again. This time, the members of the ILO were negotiating Convention 162 concerning safety in the use of asbestos. This area has been covered by four Community directives. ${ }^{29}$ Once again, the Commission took the view that the EC has exclusive competence to negotiate and

\footnotetext{
24 ibid.

25 ECJ, Opinion 2/91 (n 2) part IV - Community participation in negotiations leading to ILO conventions.

26 'Hours of Work and Rest Periods in Road Transport' (International Labour Conference, 64th Session, Report VII (2) Geneva, 1978).

27 ILO Constitution, article 19(5).

28 According to Frid (n 23) 294.

29 Council Directive 76/769/EEC of 27 July 1976 on the approximation of the laws, regulations and administrative provisions of the Member States relating to restrictions on the marketing and use of certain dangerous substances and preparations [1976] OJ L262/201; Council Directive 78/319/EEC of 20 March 1978 on toxic and dangerous waste [1978] OJ L84/43; Council Directive 80/1107/EEC of 27 November 1980 on the protection of workers from the risks related to exposure to chemical, physical and biological agents at work [1980] OJ L327/ 8; Council Directive 83/477/EEC of 19 September 1983 on the protection of workers from the risks related to exposure to asbestos at work (second individual Directive within the meaning of Article 8 of Directive 80/1107/EEC) [1983] OJ L263/25.
} 
conclude the convention. The Commission sent a communication to the Council on 16 May 1986. The communication included a recommendation of a Council decision authorising the Community to take part in the negotiations on ILO Convention 162. The Commission requested to have the task to present the Community position, according to the negotiating brief that was supposed to be established by the Council. While not disputing Community competence on the matter, some Member States took the view that the ILO Constitution did not allow the Community to take part in the Conference. ${ }^{30}$ The Council then decided that the Community together with its Member States should put the Community's position on the basis of the relevant directives. The Commission brought an action for the annulment of this Council decision on the grounds that it breached Article 228 TEC. ${ }^{31}$ However, on 22 December 1986 the Council adopted a decision which, in the Commission's view, provided a generally satisfactory solution, and therefore the Commission withdrew its action before the ECJ. ${ }^{32}$

The decision of the Council imposed full compliance with the tripartite consultation procedure of the ILO. It provided that the Commission would be involved in creating a reply to the questionnaire sent by the ILO. After the adoption of the Community's reply by the Council on a proposal by the Commission, the Commission would be competent to submit it to the ILO. Before the adoption of the reply, the consultation with employers and trade union organisations at the national level should be taken into consideration. For the preparation of the first reading of a draft convention, the Commission must propose that the Council adopts a decision authorising it to negotiate and giving it a negotiating brief. At the Conference, the Commission would then negotiate the convention. This means that the Commission would speak on behalf of the Community while working in close consultation with the Member States. This is in line with the position set up by the International Labour Office ${ }^{33}$ in 1981 . The Office position acknowledges that there is nothing in the ILO Constitution to prevent several members from expressing their view through a regional representative, which may even present amendments to the draft text on their behalf. The Council decision further specified that the delegates of

\footnotetext{
30 ECJ, Opinion 2/91 (n 2) part IV - Community participation in negotiations leading to ILO conventions.

31 Case C- 217/86 Commission v Council-removed from the register on 25/02/1987.

32 ECJ, Opinion 2/91 (n 2) part IV - Community participation in negotiations leading to ILO conventions.

33 According to Art 10 of the ILO Constitution, the functions of the International Labour Office include the collection and distribution of information on all subjects relating to the international adjustment of conditions of industrial life and labour, and particularly the examination of subjects which it is proposed to bring before the Conference with a view to the conclusion of international conventions, and the conduct of such special investigations as may be ordered by the Conference or by the Governing Body.
} 
the Member States would retain their right to speak during the plenary session of Conference. ${ }^{34}$

However, the Council decision did not contain provisions on ratification of the ILO conventions falling within exclusive Community competence. Therefore, the subject of ratification of the Convention remains controversial and it delayed the ratification processes within the EU Member States. Nevertheless, by October 2013, the Convention was ratified by 35 Member States of the ILO, among which twelve are Member States of the European Union. ${ }^{35}$

\section{3. ILO Convention 170}

The fact that the question of who had competence to conclude ILO Convention 170 was brought to the European Court of Justice in 1991 is evidence that this was a highly controversial issue within the EC at this time. Furthermore, non-judicial means to settle the disagreement, as in previous cases, were not sufficient. The Commission had sought an Opinion from the Court on the Community's competence to conclude the Convention signed in 1990 under the auspices of the ILO on safety in the use of chemicals at work. ${ }^{36}$ The main argument of the Commission was that the Community alone was competent to conclude the agreement. This was based on its internal competence on health and safety under Article 137 TEC (Article 153 TFEU). As previously noted, the controversies that had occurred earlier were addressed on the basis of ad hoc procedural arrangements. Those arrangements came to an end when the Council, with the agreement of the Commission, adopted a decision in December 1986. The material scope of the decision was strictly confined to areas falling within the exclusive competence of the Community. It was on the basis of that decision that in July 1988 the Commission submitted a proposal to the Council in relation to an ILO questionnaire on Convention 170. Several Member States contested the Community's exclusive competence to act in the matter. As a result, the Member States sent their replies directly to the ILO, thereby preventing transmission of replies at Community level. ${ }^{37}$ The reason for this was the fact that the Member States disagreed that the subject matter of the Convention was not covered by the Community's exclusive competence. The Commission, however, took the view that the exclusive competence of the Community

\footnotetext{
34 ECJ, Opinion 2/91 (n 2) part IV - Community participation in negotiations leading to ILO conventions.

35 Convention No 162 is ratified by Belgium, Croatia, Cyprus, Denmark, Finland, Germany, Luxembourg, Netherlands, Portugal, Slovenia, Spain and Sweden.

36 ECJ, Opinion 2/91 (n 2) part IV - Community participation in negotiations leading to ILO conventions.

37 ibid.
} 
was not a matter of doubt. Therefore, it wrote to the Council on 12 May 1989 and requested to be authorised to negotiate the Convention on behalf of the Community. ${ }^{38}$ The Council gave its agreement. The adopted decision also required the Commission to be in close consultation with the Member States. Furthermore, it provided that the Member States would retain their right to express views on aspects which fell within the areas of national competence. Following the adoption of Convention 170, the Commission informed the Council that it was under the legal duty to inform the International Labour Office that, in terms of Article 19(5) of the ILO Constitution, the competent authorities were the Community institutions. On that occasion, several national delegations to the Council indicated their refusal to accept that the Community had exclusive competence to conclude the Convention. ${ }^{39}$ According to numerous Member States, Convention 170 did not fall within the scope of the Community's exclusive competence. The objective of Convention 170 was to protect workers against the harmful effects of using chemicals in the workplace. According to the text of the Convention, this was about to be achieved in various ways. The Convention set out consultation procedures between Contracting States and representative organisations of employers and workers; it authorised national authorities to prohibit, restrict or regulate the use of hazardous chemicals; it laid down rules on the classification of chemical products and their transport, labelling and marketing; and it defined the relevant responsibilities of employers, and the duties and rights of workers. ${ }^{40}$

When requesting the opinion of the Court, the core of the substantive issues raised by the Commission in its request was whether the conclusion of Convention 170 fell within the competence of the Community. If the Convention was under Community competence, was that competence exclusive? Primarily, when approaching this issue, the Court found it necessary to articulate the general grounds on which the Community's implied competence may arise. Further, it found it essential to determine the circumstances in which that kind of competence may become exclusive.

The Court started its analysis with its ruling in Opinion 1/76 and the existence of the implied powers. According to the Court, the authority to enter into international commitments may arise not only from an express attribution by the Treaty, but may also flow implicitly from its provisions. Therefore, when approaching the specific question of competence raised by the Commission, the Court identified the objective of Convention 170.

\footnotetext{
38 ibid.

39 ibid.

40 On this issue, see Convention 170 of the International Labour Organisation concerning safety in the use of chemicals at work, 1990.
} 
Namely, the main objective is to prevent or reduce the incidence of chemically induced illnesses and injuries at work. Further, the Court noted that this objective fell within the social provisions of the EC Treaty. Undeniably, the improvement of the working environment to protect workers' health and safety was defined in Article 137(1a) TEC (Article 153 TFEU) as an area where the Community supports and complements national actions by means of directives setting out minimum standards. Having established the existence of internal competence over the areas covered by Convention 170, the Court had no difficulty in asserting the existence of an external implied competence.

Additionally, the Court went on by analysing whether the implied external competence was exclusive. The Court focused on the effects of the rules laid down in Convention 170, and ruled as follows:

[T] ] provisions of Convention No 170 are not of such a kind as to affect rules adopted pursuant to Article [137 EC]. If, on the one hand, the Community decides to adopt rules which are less stringent than those set out in an ILO convention, Member States may, in accordance with Article [137(4) EC], adopt more stringent measures for the protection of working conditions or apply for that purpose the provisions of the relevant ILO convention. If, on the other hand, the Community decides to adopt more stringent measures than those provided for under an ILO convention, there is nothing to prevent the full application of Community law by the Member States under Article 19(8) of the ILO Constitution, which allows Members to adopt more stringent measures than those provided for in conventions or recommendations adopted by that organization. ${ }^{41}$

According to the Court, ILO Convention 170 did not fall within the exclusive competence of the Community. The judges held that a conclusion by the Member States could not affect the content of secondary legislation being adopted pursuant to Article 137(2) TEC. The Court's conclusion was challenged by the Commission with two further arguments. According to the Commission, it would be difficult to assess whether or not a specific provision would be more favourable for the protection of working conditions. Therefore, in order to avoid a violation of the ILO Convention, Member States might become reluctant to adopt measures necessary for the working environment under Article 137(2) TEC and consequently impairing the development of Community law. The Commission argued that there was an alternative foundation for exclusivity, namely secondary legislation adopted under Article 100 TEC.

$\overline{41}$ ECJ, Opinion 2/91 (n 2) para 18. 
The Court rejected both arguments, and stated:

[D]ifficulties, such as those referred to by the Commission, which might arise for the legislative function of the Community cannot constitute the basis for exclusive Community competence. ${ }^{42}$

Furthermore, the Court pointed out that the secondary provisions adopted under Article 100 EC laid down minimum requirements. The Court made specific reference to legislation on the protection of workers from the risks related to exposure to chemical, physical and biological agents at work ${ }^{43}$ and other detailed directives adopted pursuant to this.

Having established that the conclusion of ILO Convention 170 was under the joint competence of the Community and its Member States, the Court went on to point out the following:

[I]t is important to ensure that there is close association between the institutions of the Community and the Member States both in the process of negotiation and conclusion and in the fulfilment of the obligations entered into. This duty of cooperation, to which attention was drawn in the context of the EAEC Treaty, must also apply in the context of the EEC Treaty since it results from the requirement of unity in the international representation of the Community.

In this case, cooperation between the Community and the Member States is all the more necessary in view of the fact that the former cannot, as international law stands at present, itself conclude an ILO convention and must do so through the medium of the Member States. ${ }^{44}$

Opinion 2/91 establishes the principle of non-exclusive external competences. It establishes the legal principle which makes the executive authorities of the Community and the Member States assume responsibility for the conduct of external relations. However, while the Court established that the Community has mixed external competences with the Member States on matters that are subject to Convention 170, the possibility for the Community to exercise these powers within the ILO is still quite restricted.

Even though the Court does not indicate specific ways for cooperating, the duty of doing so is established. In relation to Union representation in international organisations, the duty imposed on the Member States to cooperate is a very important issue, particularly in cases where the Member States and the Union have shared membership in interna-

\footnotetext{
42 ibid para 20.

43 Council Directive 80/1107/EEC (n 29).

44 ECJ, Opinion 2/91 (n 2) paras 25-26.
} 
tional organisations and where the Union has only observer status or is not present at all within the international organisation.

The obligation of close cooperation in fulfilling the commitments between the Union and the Member States results from the requirement of unity in the international representation of the Community and covers all stages of concluding such a convention. The Court stressed that in the case at hand cooperation was even more necessary since the Community itself could not conclude the ILO Convention and had to do so through its Member States. The duty of cooperation was developed in Opinion 1/94.

The duty of cooperation refers to all stages of external action, starting from negotiations through to the conclusion and execution of international obligations, either by concluding international treaties or agreeing to the decisions of the organs of international organisations. When negotiating with another international organisation, the Member State's positions should be coordinated, and the coordination between the position of the Member States and the Union needs to be ensured. If coordination fails and a common position is not achieved, there will be no participation in the negotiations. The requirement of unity in the international representation of the Union is incompatible with the individual behaviour of the Member States. When the shared competences are linked and complex, Member States acting alone would usurp Union powers. By agreeing to international commitments in Union areas, the states might commit the Union under international law. Therefore, there should be either coordinated action or no action at all. ${ }^{45}$ The same should apply when the Union enters an international organisation either by concluding a treaty or by agreeing to the decisions of the organs of the international organisation. It would be incompatible with the duty of cooperation for Member States and also for the Union to enter into an international commitment in the absence of a common decision to that effect. According to Ruling $1 / 78,{ }^{46}$ when implementing a mixed agreement, both Union and Member States should act in conformity with the division of their internal powers.

The duty of cooperation imposes an obligation on the Member States to take up a common position. Furthermore, the duty of cooperation applies in cases of joint competences of the Union and Member States regardless of the Union status in the international organisation.

This obligation was used afterwards as an argument by the Commission to have the country holding the Presidency to present the EU

45 For more on this issue, see C Timmermans, 'Organising Joint Participation of EC and Member States' in A Dashwood and C Hillion (eds), The General Law of EC External Relations (Sweet and Maxwell 2000) 239-247.

46 Convention on the Physical Protection of Nuclear Materials, Facilities and Transports (Ruling 1/78) [1978] ECR 2151, para 36. 
common position within the ILO. ${ }^{47}$ In that regard, the Member States and the Union will both act within the framework of the ILO. This implies that when issues of mixed competence are put on the agenda of the ILO, according to the duty of cooperation, the most effective solution of the problems should be found.

\subsection{The ILO Maritime Labour Convention}

The Maritime Labour Convention was adopted within the ILO in February 2006 and aims at promoting decent living and working conditions for seafarers and fairer competition conditions for operators and shipowners. The Maritime Labour Convention is supposed to be the fourth pillar of the international regulatory regime of quality shipping, complemented by the key conventions of the International Maritime Organisation. The Convention introduces innovative methodology and constitutes a framework instrument containing almost all the existing maritime ILO conventions and recommendations. ${ }^{48}$ However, the codification included limited or sometimes noticeable amendments to the existing provisions.

According to the Council Decision adopted on 7 June $2007,{ }^{49}$ some provisions of the Convention, especially those that refer to the coordination of social security schemes, fall within the Community's exclusive competence. Member States are free to determine their social security regimes, but it is EU law that provides for rules of coordination between Member State legislations. Coordination is necessary to avoid possible gaps in protection provided to migrant workers, and it is also needed in cases where conflicting situations implying unacceptable discrimination occur, to the detriment of the workers in question. For this reason, the Commission was actively involved in the preparation of the Convention from its outset. According to the ILO Constitution, the Community was not able to ratify the Convention, since only states can be parties. However, the fact that the Member States were authorised to ratify the Maritime Labour Convention in the interests of the European Community is important. In this respect, the European Commission proposed that the Council should give authorisation to the Member States to ratify the 2006 Convention 'in the interests of the Community'. ${ }^{50}$ According to this provision, the Member States are not entitled to depart from the Council

\footnotetext{
47 See as an example the adoption procedure of Report IV (1) 'Prevention of Major Industrial Accidents' in 1993. Denmark was presenting the common position of the EC as a country that held the Presidency at that time.

48 Convention 185 on identity documents that was signed in June 2003 and entered into force in 2005 was not subject to the consolidated instrument.

49 Council Decision of 7 June 2007 authorising Member States to ratify, in the interests of the European Community, the Maritime Labour Convention, 2006, of the International Labour Organisation 2007/431/EC.

50 ibid.
} 
position by, for example, not ratifying the Convention in question. In this manner, the Directive prevails over the national sovereignty of the Member States under international law. Since the Convention lays down the foundations of the international labour code by setting minimum labour standards, the Council found it necessary for its provisions to be applied as soon as possible. ${ }^{51}$

Despite the fact that traditionally the EU Member States held an overall position towards ILO instruments that was more favourable than the usual acceptance in other regions of the world, differences existed among Member States. ${ }^{52}$ However, the European Commission, through its positive position, tried to bridge these differences. Even though the European Commission was not part of the negotiation process and had only the status of observer, it had taken note of the favourable vote of the Member States which participated in the negotiations. According to the European Commission, 'a clear signal should be given to the rest of the world on the importance the Community attaches to the 2006 Convention and to the working and living conditions of seafarers'. ${ }^{53}$

On the initiative of the European Commission, the EC Shipowners' Association and the European Transport Workers' Federation concluded the Agreement on the ILO Maritime Labour Convention 2006 in May 2008. The Agreement makes amendments to the European Agreement on the organisation of the working time of seafarers that was concluded in Brussels on 30 September 1998. Afterwards, at the request of the EC Shipowners' Association and the European Transport Workers' Federation, the Council adopted the Directive for the implementation of the Agreement in February 2009. The Agreement on the ILO Maritime Labour Convention 2006 is supposed to enter into force simultaneously with the Maritime Labour Convention. Furthermore, the Council Directive implementing this Agreement, according to the requirements of the social partners, will enter into force no earlier than on the date of the entry into force of the Convention. ${ }^{54}$

The ILO Maritime Labour Convention put the EU capacity to incorporate new standards relating to maritime labour to the test. The Council proposed that the Member States make an effort to ratify the Conven-

\footnotetext{
51 ibid.

52 I Christodoulou-Varotsi, Maritime Safety Law and Policies of the European Union and the United States of America: Antagonism or Synergy? (Springer 2009).

53 Commission, 'Proposal for a Council Decision on authorizing Member States to ratify, in the interests of the European Community, the 2006 Consolidated Maritime Labour Convention of the International Labour Organisation' COM(2006) 288 final.

54 Council Directive 2009/13/EC of 16 February 2009 implementing the Agreement concluded by the European Community Shipowners' Associations (ECSA) and the European Transport Workers' Federation (ETF) on the Maritime Labour Convention, 2006, and amending Directive 1999/63/.
} 
tion preferably before 31 December 2010. So far, up to October 2013, Bulgaria, Croatia, Cyprus, Denmark, France, Greece, Hungary, Latvia, Lithuania, Luxemburg, Malta, Netherlands, Poland, Sweden and Spain have ratified the Convention. If the EU Member States proceed with a coordinated ratification of the new instrument, the EU will demonstrate its power to influence in the most resolute manner the future of new maritime norms.

\section{5. Denouncing ILO Convention 89 by the EU Member States}

The ILO standards which restrict women's work in difficult industrial conditions were hailed as a humanitarian advance for the protection of female workers. These standards have become an object of controversy among the ILO's social partners. ${ }^{55}$ A number of ILO instruments, starting from the 1919 Night Work (Women) Convention until the 1990 Protocol, regulate the protection of women in connection with night work. Furthermore, progress is seen in this area in the provision of protection to all night workers without sex discrimination.

The object of our interest is ILO Convention 89 concerning the night work of women employed in industry adopted in 1948, mainly because it was ratified by nine EU Member States and was denounced afterwards, since its provisions were incompatible with Union legislation. ILO Convention 89 which prohibited night work by women, describing night as a period of at least eleven consecutive hours, including an interval of at least seven consecutive hours falling between ten o'clock in the evening and seven o'clock in the morning. This was not in compliance with EU secondary legislation moving towards the protection of all workers without discrimination. This Convention became a divisive issue among the ILO social partners by the end of the 1980s. Therefore, in 1990, the ILO adopted two instruments ${ }^{56}$ which lifted the general prohibition of night work for women and limiting it to ensuring that an alternative to night work be available to them.

ILO Convention 89 was ratified by several EC Member States, among which was France's ratification in 1953. French legislation had mainly complied with the provisions of ILO Convention 89. There were various exemptions to the general prohibition of women's night work that were included in French law. Special dispensation for women in managerial or technical executive positions of responsibility was one of them, together with work in successive shifts. However, there were several conditions that needed to be met in order for these exemptions to apply. One of

\footnotetext{
55 On this issue, see EC Landau and Y Beigbeder, From ILO Standards to EU Law: The Case of Equality Between Men and Women at Work (Martinus Nijhoff Publishers 2008) 116-126. 56 Night Work Convention No 171 (1990) and the Protocol to the Night Work (Women) Convention (1990) No 89.
} 
them was a company collective agreement and consent from the sector concerned. ${ }^{57}$

Besides the exemptions from the prohibition of women's night work, the French legislation that was in line with the ILO standards was not in line with EU legislation. Before France had had a chance to ratify the 1990 ILO instruments, a preliminary ruling case started before the ECJ. In the case of Ministère Public $v$ Stoeckel ${ }^{58}$ of 1991, the Tribunal de Police of Illkrich, France, requested a preliminary ruling from the ECJ on the compatibility of the French Labour Code with Council Directive 76/207/ EEC. The ECJ strongly criticised the ban on women's night work as being at odds with the Council's Equal Treatment Directive. ${ }^{59}$ According to Council Directive 76/207/EEC, the principle of equal treatment was firmly established, meaning that there should be no discrimination whatsoever on grounds of sex. According to the Court, Article 5 of the Directive was precise enough to impose on the Member States the obligation not to lay down by legislation the principle that night work by women be prohibited in cases where night work for men is not prohibited, even if it is subject to exemptions. Therefore, the Stoeckel ruling effectively rendered the French regulation null and void. Thus, any individual could request that a French judge overturn the relevant Article (L 213-1) of the French Labour Code, which does not comply with Community law. Even though the case was decided on the basis of the French Labour Code only, without reference to the ILO Convention, following the Court ruling France denounced ILO Convention 89. However, the controversial Article (L 213-1) of the French Labour Code was not annulled. This was an issue of controversy among France and the European Commission for more than ten years after the Stoeckel ruling. France's National Assembly finally lifted the ban on night work for women in November 2000, ending the conflict with the EU.

As a result of the Stoeckel ruling, ILO Convention 89 was denounced by eight other EU Member States. ${ }^{60}$ This was done before prior discussi-

\footnotetext{
57 On this issue, see C Meilland, 'France and EU in Legal Tussle over Women's Night Work' (European Industrial Relations Observatory On-line, 28 May 1999)

<http://www.eurofound.europa.eu/eiro/1999/05/feature/fr9905183f.htm> accessed 25 May 2012.

58 Case C-345 Stoeckel [1991] ECR I-4047.

59 Council Directive 76/207/EEC of 9 February 1976 on the implementation of the principle of equal treatment for men and women as regards access to employment, vocational training and promotion, and working conditions [1976] 76/207/EEC.

60 Belgium ratified the Convention in 1952 and denounced it in 1992; Greece ratified the Convention in 1959 and denounced it in 1992; Ireland ratified the Convention in 1952 and denounced it in 1982; Italy ratified the Convention in 1952 and denounced it in 1992; Luxemburg ratified the Convention in 1958 and denounced it in 1982; Netherlands ratified the Convention in 1952 and denounced it in 1974; Portugal ratified the Convention in 1964 and denounced it in 1992; Spain ratified the Convention in 1958 and denounced it in 1992. Austria became an EU member after the ECJ ruling in 1991. However, it had ratified the Convention in 1950 and denounced it in 2001.
} 
on with the International Labour Office. Due to their future membership prospects, Slovakia ${ }^{61}$ and the Czech Republic ${ }^{62}$ denounced ILO Convention No 89 as well.

After the Stoeckel ruling, the ECJ once again referred to ILO Convention 89 in 1993 in the Levy case. ${ }^{63}$ Assuming that France had not yet denounced ILO Convention 89, the Court stated that the ban on night work for women was incompatible with the Equal Treatment Directive, unless:

the application of such provision is necessary to ensure the performance by the Member States concerned of obligations arising under an agreement concluded with non-member countries prior to the entry into force of the EEC Treaty. ${ }^{64}$

However, France had denounced the Convention on 26 February 1993, some six months before the Court's ruling on 2 August 1993. France had ceased to have any obligations under ILO Convention 89 at the date of the ruling. ${ }^{65}$

\section{The development of EU participation in and coordination of ILO activities}

Social and economic progress and improvement of living and working conditions are shared commitments of the ILO and EU. Since the first agreement between the ILO and the Communities was concluded in 1958, the two organisations have progressively developed their cooperation to further these aims. The setting in which the coordination of EU policies in relation to the ILO takes place has clearly evolved. This comes as a result of the developments in the EU's general organisational characteristics. In this context, many of the goals and activities of the various actors within the EU are well defined when they face an event such as the International Labour Conference. ${ }^{66}$ The European Commission represents the European Union in the areas that have an effect on the Union, outside the ILO Conference that is held once a year. In other areas, close cooperation between the Commission and the Presidency is required. According to Nedergaard, there are some occasions when the Presidency does not have a clear mandate from the Council of Ministers. Therefore, the time factor is sometimes very important in determining

61 Slovakia denounced the Convention in 2002.

62 The Czech Republic denounced the Convention in 2001.

63 Case 158/91 Ministère public et Direction du travail et de l'emploi $v$ Jean-Claude Levy [1993] ECR I-4287.

64 ibid.

65 More on this issue in Landau and Beigbeder (n 55).

66 P Nedergaard, 'Coordination Processes in International Organisations: The EU at the International Labour Conference in 2005' (2008) 12(3) European Integration Online Papers <http:/ / eiop.or.at/eiop/texte/2008-003a.htm> accessed 25 May 2012. 
whether or not a reading in the Council is possible before ILO conferences take place. ${ }^{67}$ Usually, the documents for ILO conferences are ready in March at the earliest. Since the meeting of the Employment, Social Policy, Health and Consumer Affairs Council needs to be prepared for June, the schedule of the Working Group for Social Affairs of the Council of Ministers is often very busy from March to May. Therefore, for practical reasons, the Presidency has a high level of discretion during the ILO conferences. ${ }^{68}$ However, in cases where it is evident that conflicts between ILO and EU regulations or policies may occur, urgent and extensive coordination meetings in the Working Group for Social Affairs of the Council of Ministers take place. These meetings aim to define common positions on issues that concern significant aspects of EU policies.

After the ECJ delivered its Opinion 2/91, the practice of having the Council of Ministers involved in the ILO Conference stopped. In 1994, the Commission presented a proposal for a Council decision that would refer to the exercise of external Community competences at the ILO Conference. The decision was mainly aimed at areas within the scope of joined competences between the Union and the Member States. ${ }^{69}$ The Council of Ministers did not conclude its discussions on the Commission's proposal. However, according to Commission officials, the Commission finds that today the proposal is used in practice in EU coordination at the ILO. ${ }^{70}$

During 2003, the Commission came up with a proposal to strengthen EU coordination and, with that, EU competences in the ILO. However, this proposal was unsuccessful, since two EU Member States - Spain and Greece ${ }^{71}$ - were reluctant to accept it. If the EU strengthened its competences, issues concerning fishing and maritime transportation would be coordinated at the EU level. Nevertheless, EU coordination plays a far greater role in the phase leading up to the negotiations. During this phase, issues are presented at meetings between national experts on ILO issues. The meetings are organised by the Commission while pending approval by the Presidency. As can be seen, in the European Union the Commission and the Presidency act jointly vis-à-vis the Member States. It is the Commission that plays the leading role until the ILO Conference starts, while the Presidency takes over during the Conference.

\footnotetext{
67 P Nedergaard, 'The European Union at the ILO's International Labour Conferences: A "Double" Principal-Agent Analysis' in KE Jorgensen (ed), The European Union and International Organisations (Routledge 2009) 153.

68 ibid.

69 Commission, 'Proposal for a Council Decision on the exercise of the Community's external competence at international labour conferences in cases falling within the joint competence of the Community and its Member States' COM (94) 2 final.

70 According to Nedergaard (n 67) 153.

71 Both countries have strong national interests in various issues concerning fishing and maritime transportation.
} 
When the ILO Conference starts, there are a number of coordinative and preparatory meetings that are held in Geneva. The meetings are occupied with the professional or technical activities of the Conference. The meetings are organised by the Commission according to an agreement with the Presidency. There are also informal exchanges on other relevant issues. Usually, it is the Commission that prepares an informational note with the intent to facilitate EU coordination on these issues.

In addition, another interesting fact is that the Commission stays in contact with the EU social partners regarding ILO issues. The Commission considers the tripartite set-up, which implies that ILO issues are to an increasing extent relevant to the social dialogue of the European Union, as, for example in the Social Dialogue sector committees. ${ }^{72}$ Before the Conference, the Commission also contacts the social partners in the European Union as well as other international actors. These extensive contacts and this intensive information from the Commission's side before the Conference starts have the purpose of easing the bargaining processes at the Conference itself where the representatives of the social partners are present. ${ }^{73}$

Although the Commission has an active role during the negotiation process before the start of the Conference, it does not play any formal role during the Conference itself. There has been an attempt by the Commission to achieve an independent status for the European Union within the ILO. However, the Commission's lobbying has not had much success.

In any case, it is the Commission that provides the Member States' representatives with information on general EU policies in the appropriate areas throughout the Conference. Furthermore, the Commission gives its interpretation of relevant EU regulations in relation to legal questions. The Commission's position during the Conference is strengthened by the presence of 15 to 25 officials from the Commission. In addition, the Commissioner for Employment, Social Affairs and Equal Opportunities most often attends the ILO Conferences. On a regular basis, the Commissioner together with the Director-General for Employment, Social Affairs and Equal Opportunities participates in the ministerial week of the Conference. This is the week when the Ministers for employment and labour are present at the Conference as well. This relatively high number of Commission officials helps the bargaining processes during the Conference. They use their expertise to improve the lines of communication and coordination and thereby enhance the common EU position.

Since the representatives of the Commission do not have a formal role during the ILO Conference, it is the Presidency that is the formal

\footnotetext{
72 Nedergaard (n 67) 156.

73 ibid.
} 
representative of the European Union. The Presidency leads EU coordination and acts on behalf of the EU Member States. ${ }^{74}$

The Amsterdam Treaty and afterwards the Nice Treaty, and especially the Lisbon Treaty, have expanded the scope of issues that are relevant for the ILO and the European Union's internal and external policies. The strategy for employment and social inclusion, social dialogue, working conditions and fundamental rights, including non-discrimination, is an issue that is relevant both to the EU and the ILO. Therefore, according to Nedergaard, the expected outcome was a demand for more pre-emptive EU coordination of ILO issues. However, many Member States act differently. The increased relevance of the ILO for the European Union is only reflected to a certain extent in their position vis-à-vis strengthened European Union coordination during the conferences. ${ }^{75}$

The same applies to the issues that have increasing importance for EU policies and that are part of different ILO policies. This especially refers to the ILO's social dimension of globalisation - the interdependence of economic, employment and social policies, trade as well as external relations, and cooperation. The same may be said for the connection between the European Union's employment strategy and the ILO's strategy for "Decent Work". ${ }^{76}$

\section{Conclusion}

EU membership in international organisations depends mainly on the EU's legal competences to join a particular organisation. ${ }^{77}$ In its Opinion 2/94, the ECJ clarified that the Union has 'only those powers which have been conferred upon it' and they must be respected 'in both the internal and the international action'. ${ }^{78}$ Therefore, whenever addressing the question of EU membership in international organisations, it must be taken into account that the Union's external action is limited by the competences which it may exercise in accordance with the objectives set by the Treaties. However, there are cases, like the one with the International Labour Organisation, where the Union has external competences

\footnotetext{
74 For more on the role of the Presidency of the EU during the ILO Conference, see Nedergaard (n 66),

75 Nedergaard (n 67) 159.

76 ibid.

77 Another factor that influences EU membership in international organisations is the fact that in most cases international organisations do not admit as full members other international organisations. Membership of international organisations is open only to States. However, international organisations have tended to become more open to accession by regional economic integration organisations.

78 ECJ, Opinion 2/94 (Accession by the Communities to the Convention for the Protection of Human Rights and Fundamental Freedoms) [1996] ECR I-1759, I-1787, paras 23 and 24.
} 
in the working area of the organisation, but cannot put them completely into action because it is not a member of the organisation.

Member States may act within the ILO and ratify conventions in the fields where the EU does not yet have any internal legislation. However, in certain areas, the Member States have more limited scope for action, which means that the Member States are impeded from independently concluding international agreements in the field of shared competences with the Union. In the areas of EU exclusive external competence, the Member States' freedom of action is restricted when it comes to the ratification of ILO conventions. One important development is the fact that the Member States were authorised to ratify the Maritime Labour Convention in the interests of the European Community. The Member States are not entitled to depart from the Council's position in cases like this, for example by not ratifying the convention in question. The Union has proceeded with the same practice in connection with ILO Convention 189 concerning decent work for domestic workers adopted by the ILO in 2011. In March 2013, the European Commission prepared a proposal for a Council Decision to enable Member States to legally ratify those parts of Domestic Workers Convention 189 that fall under Union competence. Further, in July 2013, the Council adopted a Decision authorising Member States to ratify, in the interests of the European Union, the Convention concerning safety in the use of chemicals at work, 1990, of the International Labour Organisation - Convention 170.

Since Union law is dynamic and always developing, conflicts of norms between EU law and ILO conventions are also likely to occur frequently in the future. What is very important, as the ILO points out, is that the transfer of competences to the Union does not result in Member States neglecting to follow the ILO's objectives. The aims of the two organisations coincide to a great extent and their interdependence can lead to the pursuit of common goals. The features of the EU's observer status have changed and advanced over the years. Therefore, increasingly advanced cooperation in the future will lead to many positive benefits. 